\title{
Role of Colonial Subjects in Making Themselves Inferior in Chinua Achebe's Things Fall Apart
}

\author{
Zahra Sadeghi \\ Sari, Iran \\ E-mail: zahrasadeghi68@yahoo.com
}

Doi:10.7575/aiac.alls.v.5n.6p.48

URL: http://dx.doi.org/10.7575/aiac.alls.v.5n.6p.48
Received: 11/08/2014

Accepted: 29/09/2014

\begin{abstract}
Chinua Achebe in his novel Things Fall Apart gives us a unique picture of life in Africa before the arrival of Christianity and colonization and the era afterwards. He shows how African people lost their traditional culture and values, replacing them with foreign beliefs. In this article, the way black people lived before the arrival of white people, how they encountered and reacted to white colonizers, in addition to how they converted to Christianity and subsequently to White culture, as portrayed in this novel, will be analyzed. The purpose of this study is to trace the roots of this rapid pace of colonialism back to when colonial subjects lost their original culture to the new-coming people and to what extent those colonized people were affectively actualizing their inferiority and subordination to the white society. Frantz Fanon's theories on the relation between language and culture or language and civilization, as well as his discussion of White notion of Blacks and Blacks' conception of themselves are discussed and analyzed in Achebe's masterpiece Things Fall Apart to prove that black people attempted to make up for their deep feeling of incompleteness by imitating white people and forming a white personality in a black statue as a result of their own conscious volition.
\end{abstract}

Keywords: Post-colonial Studies, Colonialism, Colonial Subjects, Things Fall Apart, Self-inferiorizing, Mimicry, Feeling of Unhomeliness, Lost Identity

\section{Introduction}

The fact that it took just a hundred years (1857-1960) for the British to rip apart a society that had taken thousands of years to develop proves that European colonialism was an influential and strong agent of the change in Igbo communities. Both Christianity and Western education swept the Igbo people off their feet with an outstanding speed. Even those community leaders who had pretended and planned the wars of resistance converted to Christianity and helped in the construction of schools and churches. The reason of this high speed change can be traced and explained through these factors: education, willingness to change, disintegration of previous ties and birth of new ones. One reason behind this sudden rush to accept Western civilization is that Igbo people find and understand the importance of Western education in the progress of their life. A hundred years ago, Igbo people could hardly read or write but today we can see Igbo professors, Igbo medical practitioners, scientists, engineers, lawyers, and other professionals who occupy important positions in different parts of the globe. A second explanation is that the Igbo people were, and still are, very eager to accept change. They accept to change in order to make material progress. The third is that as the ties that bound the communities disintegrated, the Igbo found new ones in Christianity and Western education and the result was a community of Christian and Western-educated Africans. Significance of this study is to analyze how Achebe portrays the process of colonization and in this regard, matters effective in actualization of colonization are going to be discussed with regards to the selected novel.

Colonialism is an important factor in cultural production and many of cultural constructs in all over the world and it is English and English language teaching which are at the center of the contemporary world. Colonialism and imperialism are among those interesting critical debates throughout the world which are not and cannot be limited to any specific nation and any particular time because they can happen to any nation in any time. The literature written in those eras about Africa was in favor of colonization and mostly tended to support the policy of the British regarding African people and helped the colonizers fortify the colonial rule as an agent of wisdom, education and sophistication brought to the primitive peoples without any valid civilizations of their own. These written works represented Africa as a dark continent composed of irrational, undifferentiated and childlike peoples governed by superstition rather than reason, a nation too ready to accept and welcome the arrival of the colonizers and too ready to, indeed, worship the white man. Such a picture is presented in Conrad's Heart of Darkness and Cary's Mister Johnson. In addition, such an image of African people is presented even more terribly and simplistically by Rider Haggard, Edgar Wallace and a number of movie directors in their works.

There was no field of academic study known as "postcolonial studies" before the late 1970s and it was in the 1980s that postcolonial studies emerged. Today, "postcolonial studies" is included not only within the Euro-American academy but also in universities in many countries of the formerly colonized world. It is both a subject matter and a theoretical framework (Tyson, 2006: 418). As a subject matter, it analyzes literary texts written by those writers who experienced 
colonization and wrote their works in response to this colonial domination such as Ngugi wa Thiong'o and Chinua Achebe. As a theoretical system, postcolonial criticism tries to find out the performances of colonialist and anticolonialist ideologies, that is, to examine the ideologies that forced the colonized people to feel inferior in front of the colonizer's superiority. Different figures described the term "postcolonial studies" and one of the most important of which was Homi Bhabha whose works has been very influential in defining the parameters of postcolonial studies. In his essay, "The Postcolonial and the Postmodern: The Question of Agency" in The Location of Culture he states that:

Postcolonial criticism bears witness to the unequal and uneven forces of cultural representation involved in the contest for political and social authority within the modern world order.... As a mode of analysis, it attempts to revise those nationalist or "nativist" pedagogies that set up the relation of Third World and First World in a binary structure of opposition. The postcolonial perspective resists the attempt at historic forms of social explanation. It forces recognition of the more complex cultural and political boundaries that exist on the cusp of those often opposed political spheres. (Lazarus, 2006: 3)

According to Bhabha postcolonial does not mean what it sounds_after colonialism_and it ceased to be a historical category but is a social pathology and thus opposed to class analysis. Anthony D. King gives a definition of postcolonial studies in "Writing Colonial Space" in Comparative Study of Society and History (1995) and refers to the relationship between post-structuralism and postcolonial criticism. In a passage in Discourse on Colonialism (2000), Aime Cesaire skillfully used rhetoric-political gesture of 'the empire writing back' and took on the position of a speaking subject to throw the various apologies for colonialism back in the faces of the colonizers:

They talk to me about progress, about "achievement", diseases cured, improved standard of living.... But I am talking about societies drained of their essence, cultures trampled underfoot, institutions undermined, lands confiscated, religions smashed, magnificent artistic creations destroyed, extraordinary possibilities wiped out.

They throw facts at my head, statistics, mileages of roads, canals, and railroad tracks.

I am talking about thousands of men sacrificed to the Congo-Ocean. I am talking about those who, as I write this, are digging the harbor of Abidjan by hand. I am talking about millions of men torn from their gods, their land, their habits, their life- from life, from the dance, from wisdom. (Lazarus, 2006: 8)

White colonizers' aims were denigration of "native" cultures and silencing of "native" voices, but of course colonized intellectuals resisted to these colonial ideologies and among the best-known examples of such resistance are those written by Chinua Achebe in his "auto-biographic" novel Things Fall Apart and by Aime Cesaire in his Discourse on Colonialism. The other influential writer in postcolonial criticism is Victor Uchendu who tries to sketch in the life of African people in their actual life in his The Ego of Southeast Nigeria (1965). This work can be a good source of authentic information about the life of Achebe's subjects in his works. In C.L.Innes' Critical Perspectives on Chinua Achebe (1979), different approaches to and perspectives on various aspects of Achebe's works are presented with a sharp look at both literary and societal properties of black people. This can be a remarkable source for a more comprehensive study of Achebe and his subjects. Neil McEwan in his Africa and the Novel (1983) reviews African novel in its flourishing recent stage, the past few decades. In this work McEwan adopts a socio-literary approach to point at critical turning point of African Literature. A brilliant source of authentic materials on how Africans come to identify themselves can be found in Kalu Ogbaa's God, Oracles and Divination; Folkways in Chinua Achebe's Novel (1992).

Chinua Achebe in his novel Things Fall Apart (1958) portrays three stages of pre-colonial, colonial, and postcolonialcontact world of Africa representing a history of colonialism. He skillfully depicts the way in which African people lose their traditional cultures and values receiving and replacing some new and foreign beliefs. What constitutes his novel is a combination of what he knew of the elements of the novel in general, being familiar with this type of novel especially novels like Joyce Cary's Minster Johnson and Joseph Conrad's Heart of Darkness in addition to the oral narratives of Ibo culture in the light of Achebe's own creation and imagination which lead to produce a new kind of writing. What Achebe had in his mind as the purpose of writing, affected his way of portrayal of colonialism.

Chinua Achebe is known as the most popular and widely read of current African writers in both African continent and abroad. He gained this reputation by his first novel, Things Fall Apart (1958), which won him the Margavel Wrong Memorial Prize as well as grants and scholarships. To get to know the significance of Achebe's literary endeavors among his co-African authors within the vast oeuvre of African Literature another important book can be very helpful: Dennis Duerden and Cosmo Pieterse's African Writers Talking: A Collection of Radio Interviews (1972). This work provides a rich collection of interviews with literary giants of Africa including Achebe.

Known as "the father of the African novel" Achebe is best known for his fictional works foregrounding the political struggles of Nigeria. He grew up in a time when Africans were beginning to protest against European policy and their intrusion into African peoples' life and question the cultural assumptions the colonizers used to justify their intrusion and policy. Like many of his contemporary generation, Achebe was given a British education, first in the local mission school and then at Government College in Umuahia, and finally at University College, Ibadan, where he studied medicine. He soon changed his field and turned to literature which included works of Shakespeare, Milton, Wordsworth and novels of Conrad, Greene and Cary on Africa. As a result Achebe grew up "at the crossroads of cultures" (Innes, 1979: 1). On the one hand he was confronted with Bible and sang hymns night and day and on the other hand his relatives offered food to idols. He decided to describe what was going on in his first novel and many readers might find some useful knowledge of traditional Ibo society in his novel as well as values brought by white colonizers because 
Achebe experienced both cultures and was able to shift from one to another. He gives a description of the life of African people in their actual life during colonization and how they come to identify themselves. As the title of his novel indicates, Achebe debts to Yeats' poem, "The Second Coming" (1921) in which different phases in human history are given. In this work succession of momentous cycles are given in which the pre-Christian era gives way to the coming of Christ and this Christian phase followed by a new and terrifying unknown cycle, by the new "cradle" and the new "Bethlehem" of another era or "coming". The same as what happens in this work presented in Achebe's work in which nineteenth century Africa witnesses the end of an era and the beginning of twentieth century new era characterized by Europeanization which leads to yet another stage of postcolonial Africa. Based on Yeatsian philosophy no civilization can remain static and no civilization can develop towards perfection forever. Both these conditions would certainly collapse as a result of both internal and external factors and what replaces it will be opposite to itself and consists of those values which were undervalued and forbidden by the previous idea.

In this article, different elements related to the colonialism, post-colonialism and their actualization in Achebe's novel, Things Fall Apart, will be discussed to come to this result that the process of colonization was not done merely by white colonizers but with the help of colonized people. This study will benefit from Ogbaa'a invaluable thick descriptions of development of Achebe's worldviews. Hopefully, traces (or absence) of Western influence on the culture of African colony will be found with the help of this book. This research uses Achebe's novel to introduce 'Colonial Subjects' and shows how Achebe portrays them to get this conclusion that African colony was not shaped by outside forces but from within.

\section{Discussion}

\subsection{Double View of Society Portrayed in the Novel}

Things Fall Apart has significant themes such as love, compassion, colonialism, achievement, honor, and individualism and in order to expose all these themes Achebe used different devices, such as proverbs, folktales, rituals, and different characters and episodes to provide a double vision of the Ibo society of Umuofia and the main character, Okonkwo. The double view of society is manifested in his portrayal of this clan which is ritualistic and rigid but at the same time in many ways flexible. In this society child is valuable but we see that the innocent loving child, Ikemefuna, is denied of love and life and is killed by the rigid tribal laws and traditional customs. Looking at this tribe from outside, we find it as a world of serenity, harmony, and communal activities but the reality is that inwardly it is torn by the individual's personal doubts and fears. The other manifestation of this nation's duality is the society's adaptability to change in different situations which is portrayed in Ogbeufi Ezeudu's comment on the punishment of Okonkwo for beating his wife and violation of the sacred Week of Peace in chapter four which shows to what extent they are ready to change their customary code and alter their way of life when confronted with a new contradictory situation. Achebe skillfully juxtaposes contradictory events and elements to give a complete, if self-contradictory, view of the society. Achebe presents this duality in the society in order to create and intensify the sense of tragedy and help the reader understand the reason of Okonkwo's downfall.

\subsection{Communal Spirit}

One of the important aspects of the Igbo life is its communal spirit. All the people are aware of their dependence on their kin group and community. They contribute to the group to which they owe so much and it seldom happens that a person detaches from the group to which he belongs. They care for their community and everyone knows it his duty to be a conformist to the rituals and customs of his community. If we consider this pre-colonial situation and compare it to the situation when a Western country dominates this community and change it to a new one, we may expect these Igbo people to act like before and follow their community which is now in the hand of white people. What Achebe portrays in his novel fulfills our expectation; little by little most of the people turn to new rules and put away traditional customs in order to be a conformist and act according to the taste of the majority. Nonconformity had been considered illegal and those nonconformist figures, like Okonkwo, would be punished. If Igbo people had not been so much dependent to their community and had accepted differences among themselves, they would have confronted colonialism better, so that they could avoid the destruction of most of their traditional cultures. Their simple-mindedness and intolerance to the differences make them destroy figures like Okonkwo.

\subsection{People's Lack of Experience}

The other important and influential factor in the colonized people's defeat in front of newcomers is their lack of experience. In the first part of the novel at a betrothal ceremony men are discussing the strange habits of their neighbors, where West culture enters and dominates and everything is turned upside-down. Obierika says, 'It is like the story of the white men who, they say, are white like this piece of chalk and who have no toes' (Achebe, 2002: 67). These jokes used in their discussion foreshadow colonialism waiting them. None of them at that time were aware or even anticipated that one day they would act like those they were deriding. None of their belief systems, religious codes and practices had been challenged before, and now they cannot evolve strategies for adaptation or confrontation. Their disability to confront and adopt new beliefs leads to the reversal of norms and falling apart of things they had honored for centuries. For example, what happens for that sacred python proves that no one thought that their sacredness would ever be challenged. The evil forest is no longer evil and the outcasts become no longer outcasts. The objects and rituals of traditional sacrament are destroyed and those things once were considered wrong are no longer wrong. A reversal of beliefs takes place in which everything which had been norms for centuries now are challenged and, on the other hand, things which had been considered forbidden now become common. 


\subsection{Lost Identity}

Among black schoolboys there is such kind of conception that they identify themselves with explorers in search of truth_which is an all-white truth and which can be gained only among white people who are the bringer of civilization. Such a young Negro will subjectively adopt everything brought by white men and one can see in the young Blacks the formation of an attitude and a way of thinking which are basically and totally white. What a Negro strives to do and the outcome he wishes to gain is to conduct himself like a white man but there will remain an everlasting feeling of fear or anxiety in him because the fact is that he is a Negro and will remain a Negro.

Frantz Fanon in his book Black Skin, White Masks in the sixth chapter 'The Negro and Psychopathology' says that "Wherever he goes, the Negro remains a Negro" (2008: 133).He shows the notion of a white man who believes that a Negro always remains a Negro and his reason is that his body is black, his language is black, so his soul must be black too, and because soul is something innate, exists from the birth and lasts to the death without any changes, it is not in one's control to transform or shape in the way he desires. This kind of feeling penetrates and affects Black people's conception of themselves. They admit Whites' judgment of their color and the validity of their hatred of Blacks. Instead of reacting against anti-Negroism, the Negro turns himself into an anti-Negro. In this way a Negro acts like a Jew who encounters with anti-Semitism would turn into an anti-Semite which is shown in Satre's The Reprieve, in which Birnenschatz finally acts out his disavowal with an intensity that borders on dementia. Nwoye had the same feeling and “... he was happy to leave his father. He would return later to his mother and his brothers and sisters and convert them to the new faith" (Achebe, 2002: 139). He might return but not to his father and this return is to change other member of the family.

\subsection{Language in Things Fall Apart}

In this novel the white man's failure to understand African customs is because of his ignorance of the language of these people. On the other hand, new values enter into the African culture by an alien European culture by means of its language. Frantz Fanon explains the relation between language and culture or language and civilization. He believes that in order to change a nation's culture the first step is to change their language. Susan Beckman's impressive article "Language as Cultural Identity in Achebe" minutely counts elements of cultural identity as embodied in language within literary works of great figures, Achebe being one. Beckman's article can help this study maneuver into optimal middle ground between language and identity.

In this novel this transformation is done through education in mission schools. Colonized people confront the culture of the colonizer when they face its language. Igbo people want their children to progress and therefore education, one of the necessities to get success, is important to them. This education is gained from the missionaries, those white people. They send their children to cities to be educated and call them the "sons abroad". These sons abroad are the prestige of not merely a family but of the whole village. This idea encourages other at home to follow the same model and know it as a matter of shame not to educate anybody abroad. As we see, there are few Igbo leaders today who did not attend the mission schools and in this way much of their educational progress owes to the missionaries. When they attend those schools they are forced to learn and accept new things irrelevant to their culture and belief system. It is because of the fact that they know themselves inferior to the white men and know it their obligation to follow and imitate white men or soon become their slaves. They want modern development and they know that these new improvements such as hospitals, maternity centers, schools, marketplace, and council halls can be gained if they follow White Way. To those people, the physical presence of these facilities in their village is a source of prestige for which they are prepared to pay in any form. They are sure that they cannot contest white fellows because they are superior to Blacks, so the only way to have those facilities, educated head, equal to whites, is to be subordinated and follow them as a model. We can see that Nwoye in Things Fall Apart after being punished and beaten by his father because of his attendance in the church left the $o b i$ and never returned. He wanted to find a solution for his problems and turned to white people and their belief system. "He went back to the church and told Mr. Kiaga that he had decided to do to Umuofia, where the white missionary had set up a school to teach young Christians to read and write" (Achebe, 2002: 138-139).

\subsection{Nwoye}

One of the examples which show people's desire for a new way of life, a new belief, and the changes brought to them is Nwoye, Okonkwo's son, who is one of the first ones converts to Christianity and departs from his indigenous belief system. Nwoye has been ill-treated by his father over many years for not being masculine and brave enough. The psychological battering he has received from his father leads him to find solution from outside which makes him accept the new belief system with open hands. Unlike his father, he is highly flexible to new things and is tired of all those traditional and old-fashioned Umuofian belief system and finally takes refuge in Western community. There is a big contrast between Okonkwo's personality and that of his son, Nwoye, which is more emphasized by the way Achebe portrays Okonkwo's predisposition for his daughter, Ezinma. In the process of the novel we can see the gradual separation between Okonkwo and his son, and that gradual breakdown of their normal relationship ends up with Nwoye's final alienation from his father and all those traditional indigenous customs which prevent a resolution. Nwoye's rejection of his father's values, customs and religion resembles his rejection of his society and his defection to Christianity, later on, has a double significance; it is an act of revolt against his father as well as a rejection of the society to which he belonged. 


\subsection{Okonkwo}

Killam in his The Novels of Chinua Achebe (1969) states that "Okonkwo was one of the greatest men of his time, the embodiment of Ibo values, the man who better than most symbolizes his race" (Innes, 1979: 92) to emphasize on the role of Okonkwo as a representation of certain values fundamental to the Umuofia society. The problem with Okonkwo's personality is that he is so obsessed with single-mindedness and egocentricity that he cannot hear or accept any idea different from his own. His downfall stems from his different character comparing to other Igbo people that makes him alone and powerless. Outside factors accelerate his tragic movement and because of his own mental attitude, which separates him from other people, his downfall is inevitable. His emphasis on manliness and rigidity is reflected in his impatience with others, especially with his own son, Nwoye:

You stood for manliness, and he who could feed his family on yams from one harvest to another was a very great man indeed. Okonkwo wanted his son to be a great farmer and a great man. He would stamp out the disquieting signs of laziness which he thought he already saw in him. (Achebe, 2002: 30)

According to Okonkwo manliness means fierceness or violence. His violence is represented in his reaction to his wife who returns home late and does not prepare the husband's meal in time. He beats her mercilessly without considering the "week of Peace" in which beating and violence is considered taboo: "His first two wives ran out in great alarm pleading with him that it was the sacred week. But Okonkwo was not the man to stop beating someone half-way, not even for fear of a goddess" (Achebe, 2002: 27). It shows Okonkwo's bravery that he doesn't fear even a 'goddess'. . The same violence and disobedience he represents in front of a goddess is represented in front of colonizers and has the same tragic results for him. He is punished via the judgment of the earth goddess Ani, and his resistance to the process of colonization leads to his tragic result that even those who were once his friends become his enemies and he prefers suicide to that kind of miserable life. His participation in the killing of Ikemefuna despite he loves him from inward proves his preoccupation with violence. He couldn't taste any food for days after the death of the boy and didn't sleep at night. Even while killing that boy Okonkwo "looked away" (55) but he didn't have any choice but cooperating in killing to prove his manliness. David Carroll in his "Chinua Achebe" (1990) points to the limitations Okonkwo places on his relationship to and acceptance of Umuofian's standards and the sympathy and critical judgment the novel arouses in the reader:

As Okonkwo's life moves quickly to its tragic end, one is reminded forcibly of another impressive but wrongheaded hero, Henchard in The Mayor of Casterbridge. They share in obsessive need for success and status, they subordinate all their private relations to this end, and both have an inability to understand the tolerant, skeptical societies in which their novel single-mindedness succeeds.... Viewed in the perspective of the Wessex, rustic way of life, Henchard is crass, brutal, and dangerous; but when this way of life as a whole is threatened with imminent destruction, then his fierce resistance takes on a certain grandeur. The reader's sympathy describes a similar trajectory as it follows Okonkwo's career. By the values of Umuofia his inadequacies are very apparent; but when the alien religion begins to question and undermine these values, Okonkwo, untroubled by the heart-searching of the community, springs to its defense and acts. (Innes, 1979: 93)

When he was in exile in his mother's land, Uchendu, one of the elders, decided to lecture him about the importance of feminine qualities but Okonkwo was blind to anything out of his principles. Uchendu wanted to remind Okonkwo of the doom results of denial of feminine principles which have happened somehow for Okonkwo who was alienated from his clan, his family, and even himself. But Okonkwo couldn't answer Uchendu's question because he was so single-minded that he couldn't accept anything opposed to his code of action. Okonkwo and his downfall, suicide and dehumanization are reflections of his society. This novel is the tragedy of one man as well as one society. It shows his personal conflicts and the contrariness of his destiny while the collapse of the order and values of a society. All Okonkwo's clansmen become his enemies and no one supports him when he kills the messenger. When he killed that messenger he knew that he was right and believed that others confronted something too big for them and could only submit. When he found that the world he belonged to was dead, went away and preferred to hang himself. The reader can realize that Okonkwo's suicide was not just his end but it was the end of a way of life.

\section{Conclusion}

African literature has changed during different eras, flourished in the oral form with native language in Pre-colonial period and then changed into the written form borrowing a foreign language with a different content in colonial and post-colonial periods. The first African novel written in English was J.E. Casely Hayford's Ethiopia Unbound: Studies in Race Emancipation (1911) which moves between fiction and political advocacy like other literary works written in this era. It was in this period that African plays began to emerge. The first play written in English was The Girl Who Killed to Save (1935) by Herbert Isaac Ernest Dhlomo. Literature written in colonial period was mostly slave literature increasingly showed themes of liberation and independence. In postcolonial period when African nations gained their independence in the 1950s and 1960s, African literature flourished dramatically and appeared on bests of lists compiled at the end of the $20^{\text {th }}$ century. African writers were free to choose the language for their writing and wrote both in western languages such as English, French and Portuguese and in traditional African languages. The most prevalent themes of postcolonial literature are the clash between Africa's past and present, between indigenous and foreign, between tradition and modernity and between Africanity and humanity. Although some of postcolonial literature was produced by the colonizers but much of it was written by those writers who were once colonized and now try to show their objection to the whites' interference with their life and reject black peoples' inferiority imposed on them in their 
literature. Some of the authors who experienced the colonization and felt the death of some of their traditional cultures tried to reject the colonialist ideology and renew their own indigenous, native customs. Some of these writers like Ngugi wa Thiong'o wrote his works in his own local language but these works could not survive and fulfill the author's aims, because for the most part they had little chance of surviving in publishing industry both in their own country and internationally which required the universal, international language_English. On the other hand, there were some other writers who preferred to write in English because it was the language which they learned to write and because they wanted to nationalize their work and declare their rejection of colonialism to the world. Chinua Achebe was among those writers who found English as a world language which could facilitate and accelerate the emergence of his works to the global politics. It seems that Achebe also was under the influence of colonization as he states in Morning Yet on Creation Day that "[F]or me there is no other choice. I have been given the language and I intend to use it" (Tyson, 2006: 422).

It is essential to investigate the relationship between African literature and the psychopathology of language used in writing these works. This relationship is important because it produces specific authors as well as peculiar themes. Chinua Achebe is certainly a sufficient choice in this regard because the Nigerian's fiction shows his preoccupation with language, not merely as a communicative device, but as a cultural tool. Language is the "embodiment of its civilization and therefore represents or dramatizes modes of perception within its cultural grouping" (Innes, 1979: 24).

"Every dialect is a way of thinking" (Fanon, 2008: 14) and to speak of a language is to speak of a culture which is presented in the form of education. In chapter twenty of Things Fall Apart in a conversation between Okonkwo and Obierika the close relation between language and culture is presented:

"Does the white man understand our custom about land?" "How can he when he doesn not even speak our tongue? But he says that our customs are bad; and our own brothers who taken up his religion also say that our customs are bad.... He came quietly and peaceably with his religion.... He has put a knife on the things that held us together and we have fallen apart. (Achebe, 2002: 160)

As we see Obierika seems to voice Achebe's idea about colonialism and white colonizers' disability to understand the culture of Igbo people without speaking their language. It sums up how colonizers usurp the control of Igbo peoples' life little by little and finally making their life falling apart. These colonizers were clever enough to present their language in the form of education in order to introduce their values through an educational system and change black people.

Education is seen as a means to instruct the black people and to make them be aware of the benefits of colonialism and European knowledge in order to produce a well-ordered, submissive nation. Achebe portrays this process in his novel, Things Fall Apart, in which white colonizers' arrival is accompanied with their instruction of their language, religion, and culture to the native people. First, they built their missionaries to show their good intention of civilizing the uncultured black people and attracted the native peoples' attention; by this act they started to make black people more familiar with the new language to pave the way for changing their language as well as their religion which is presented in the construction of the church.

One reason behind this sudden rush to accept Western civilization is that Igbo people find and understand the importance of Western education in the progress of their life. A hundred years ago, Igbo people could hardly read or write but today we can see Igbo professors, Igbo medical practitioners, scientists, engineers, lawyers, and other professionals who occupy important positions in different parts of the globe. A second explanation is that the Igbo people were, and still are, very eager to accept change. They accept to change in order to make material progress. The third is that as the ties that bound the communities disintegrated, the Igbo found new ones in Christianity and Western education and the result was a community of Christian and Western-educated Africans.

Some critics believe that postcolonial criticism is itself a form of cultural imperialism (Tyson, 2006: 425). The reason behind this statement is that many of those postcolonial critics were from professional and intellectual ones who were educated at European universities and lived in that situation, so were far from colonized people of inferior status and had little in common with these poor, exploited peoples, therefore, their criticism neither reject colonialism nor postpone it, but in some cases renew and retain colonial discourses. This last hypothesis can be a subject of research for students of literature as well as those who are interested in the significance of literature in history of African colony.

\section{Reverences}

Achebe, C. (2002). Things Fall Apart. New Delhi, Allied Publishers.

---. (1992). Things Fall Apart/Chinua Achebe; with an Introduction by Kwame Anthony Appiah. New York, Knopf, Distributed by Randsom House. Retrieved from

http://www.randomhouse.com/knof/classics/intro/thingsfallapart_achebe.pdf/.

Bressler, Charles E. (2007). Literary Criticism: An Introduction to Theory and Practice. $4^{\text {th }}$ ed, New Jersey, Pearson Prentice Hall.

Carroll, D. (1980). Chinua Achebe. London, Macmillan Press.

Cesaire, A. (2000). Discourse on Colonialism. New York, Monthly Review Press. 
Duerden, D. \& Pieterse, C. (eds.) (1972). African Writers Talking: A Collection of Radio Interviews. London, Heinemann Educational Publishers.

Eagleton, T. (2008). Literary Theory: An Introduction. Blackwell Publishing.

Edwards, P. and Carroll, D. (1962). An Approach to the Novel in West Africa. Clark Atlanta University.

Fanon, F. (2008). Black Skin, White Masks. United Kingdom, Pluto Press.

Gordon, A.A. \& Gordon, D.L. (eds.) (2013). Understanding Contemporary Africa. $5^{\text {th }}$ ed. Boulder, Lynne Rienner Publishers.

Habib, M.A.R. (2011). Literary Criticism from Plato to the Present: An Introduction. Willey-Blackwell. Innes, C.L. \& Lindfors, B. (eds.) (1979). Critical Perspectives on Chinua Achebe. London, Heinemann. Iyaser, S.O. (1974). "Narrative Techniques in Things Fall Apart", New Letters, Vol. 40, No. 3, spring.

King, A.D. (1995). "Writing Colonial Space" Comparative Studies in Society and History. Vol.37, Issue.3, pp.541-554. Lane, L.R. (2006). The Postcolonial Novel. United Kingdom, Polity Press.

Lazarus, N. (2006). The Cambridge Companion to Postcolonial Literary Studies. New York, Cambridge University. Leitch, V.B. (ed.) (2010). The Norton Anthology of Theory and Criticism. New York, WW. Norton \& Company. Lloyd, P.C. (1967). Africa in Social Change. Penguin Books.

Lodge, D. (1984). The Language of Fiction. Routledge and Kegan Paul.

Lodge, D. \& Wood, N. (eds.) (2000). Modern Criticism and Theory. $2^{\text {nd }}$ ed. Longman.

McEwan, N. (1983). Africa and the Novel. London, the Macmillan Press LTD.

Mphahlele, E. (1962). The African Image. Praeger.

Ogbaa, K. (1992). Gods, Oracles and Divination: Folkways in Chinua Achebe's Novels. Trenton, New Jersey, Africa World Press.

Stock, A.G. (1970). "Yeats and Achebe", The Journal of Commonwealth Literature. March, pp. 105-111. 